Jan Piątkowski (10) https://orcid.org/0000-0001-5249-9024

Nicolaus Copernicus University in Toruń

Beata Rutkowska (i) https://orcid.org/0000-0002-1920-8261

Nicolaus Copernicus University in Toruń

\title{
THE STATUTORY MODEL OF THE POWERS OF A COMPANY TRADE UNION ORGANIZATION AND A LAW IN ACTION
}

\begin{abstract}
Any legislation must be assessed from the point of view of its practicability. Legislation and the application of law are closely correlated. The law must be the law in action. Based on this assumption, the overall assessment of the statutory model of the powers vested in a trade union organization is largely negative. The legislator did not provide effective tools, i.e. legal mechanisms enabling the functioning of company trade union organizations at the majority of Polish employers, and thus did not create the legal conditions for the functioning of proper and intended relations between the entities of collective employment relationships. This results, among other things, from a failure to adapt trade union legislation to the dynamically changing socio-economic conditions and needs of the modern labour market. Lack of the legislator's activity in this respect raises concerns as to the future of the trade union movement in Poland.

Słowa kluczowe: zakładowa organizacja związkowa, międzyzakładowa organizacja związkowa, monopol związku, przedstawicielstwo osób wykonujących pracę zarobkową, dialog społeczny, układy zbiorowe pracy, porozumienia zbiorowe, spory zbiorowe

Keywords: company trade union organization, inter-company trade union organization, union monopoly, representation of people performing gainful employment, social dialogue, collective labour agreements, collective agreements, collective disputes
\end{abstract}

ASJC: 3308, JEL: K31

I. Company trade union organizations constitute an important link in the trade union movement in Poland. In 2018, 9.8 thousand company-based and 2.4 thousand intercompany trade union organizations operated in Poland (Departament... 2019). The issues concerning these entities are central issues of modern labour law, especially of 
one of its basic areas, i.e. collective labour law (see e.g. Gładoch 2008; Hajn 2012; Baran 2019, pp. $159 \mathrm{ff}$ ). The powers of company trade union organizations are at the core of the indicated issues (see e.g. Świątkowski 1984; Goździewicz, Myszka, Piątkowski 1991; Salwa 1998; Piątkowski 2008), yet not only the powers decreed by an act (strong powers), but also those resulting from the general principle that what is not legally prohibited is legally permitted (weak powers) (Nowacki, Tabor 1994, p. 34). These powers are based on the general formula of trade union activity, the content of which is the representation and defence of the professional and social rights and interests of employees and other entitled persons, including persons in non-labour employment relationships. The activities in question are essentially concentrated at the level of the places of employment. Here, i.e. in the immediate environment of people performing paid work, at the will of the legislator himself, is where the most important trade union powers are concentrated. Therefore, one should share the view expressed in the doctrine that the concentration of trade union activity at the workplace level is a basic feature of the model of the Polish trade union organization movement, which in fact is a company model (Hajn 2002, pp. 438 and $443 \mathrm{ff}$ ).

II. The powers of a company trade union organization are scattered over various legal acts, which results, inter alia, from the absence of an act that unifies the collective labour law, i.e. the Collective Labour Law Code (for more information on the codification of collective labour law see e.g. Pisarczyk 2019, pp. $149 \mathrm{ff})$. These powers are so extensive that they permeate many labour law institutions. They refer to, inter alia, participation in the creation of favourable working conditions, influencing the employer's decisions, especially those related to the termination of the employment relationship with an employee represented by the union (opinion, consent, and objection), controlling the employer in terms of compliance with labour law, and in particular with the regulations and principles of occupational health and safety, or asserting rights in court (such as bringing action for the benefit of employees or the union's direct claim that the employer allocates funds for the company social benefits fund). A wide range of powers of a company trade union organization encourages theoreticians of law to present them on separate planes, with the classifications adopted in this subject seem to be of a subjective nature.

These powers are characterized also by their generic diversity. The legislator granted various rights to the company trade union organization-from the co-creation of the company labour law and proper working conditions to the participation of the organization in the taking of individual decisions by the employer in relation to the employees-in order to create a possibility of its broad influence on the legal status of employees and other persons entitled to be associated in trade unions.

The unprecedented importance of the leading trade union rights at the workplace level is also a characteristic feature of trade union rights. The most significant powers for all employees, including those who are not members of the organization, refer to the co-creation of autonomous sources of labour law-collective labour agreements 
and other collective agreements, and the shaping of the content of remuneration regulations (more broadly see e.g. Goździewicz 1996; Góral 2013; Musiała 2013), which, combined with the right to initiate collective disputes (more broadly Cudowski 1998), and announce strikes (more broadly Grzebyk 2019), have an unquestionable value in collective employment regulations and collective employment relationships. The powers vested in the company trade union organization in this respect are strategic for the assessment of the importance of the union's powers and for the theoretical and dogmatic presentation of the position of this entity not only in the workplace system, but also-or perhaps above all-in the dialogue of social partners, which constitutes the content of one of the principles of the economic system of Poland (Art. 20 of the Constitution of the Republic of Poland of 2 April 1997, Dz.U. 1997, No. 78, item 483, as amended, hereinafter referred to as: "Constitution"), and in the system of representation of persons performing gainful employment. In the model of the trade union movement in Poland outlined by the legislator, these powers are so significant that they cannot be overestimated in any way.

III. Any legislation, including legislation on the powers of a company trade union organization, must be assessed from the point of view of its practicability. Legislation and the application of law are closely correlated. The law must be the law in action. From this perspective, it is particularly important to what extent the legislator has provided effective tools, i.e. legal mechanisms enabling a company trade union organization to use its statutory rights, and thus whether it has created legal conditions for the functioning of proper and intended relations between entities in collective employment relationships. Speaking more generally, it is a question of assessing whether the statutory model of powers vested in a company trade union organization is comprehensive in nature (Piątkowski 2012, pp. $67 \mathrm{ff}$ ), as the union does not have to make use of all of its powers, which is often an element of trade union tactics. However, it must have the possibility of such action guaranteed to it by the legislator.

Ensuring that the statutory model of the powers vested in a company trade union organization can operate in practice depends, among other things, on whether the model takes into account the changing social and economic conditions under which it is binding, so as to meet the needs of the present times. One may have doubts about this. The binding trade union legislation in its general form dates back to the end of the $20^{\text {th }}$ century. It was and still is aimed at large workplaces. In addition, the statutory model of the trade union movement combines all the rights of an organization at the workplace level with an association of at least 10 members-employees or other persons performing gainful employment (Art. $25^{1}$ of the Act of 23 May 1991 on trade unions, Dz.U. 2019, item 263 consolidated text, hereinafter referred to as: "a.t.u.;" more broadly: Rutkowska 2019, pp. 217 ff). Meanwhile, the current labour market is dominated by microenterprises employing up to 9 persons performing gainful employment. In 2017, there were over 2 million micro-enterprises in operation, which constituted as much as $96.5 \%$ of all enterprises in Poland, and they employed nearly 4 million people- $40 \%$ of 
the total number of people working in the enterprise sector (Zakrzewski, Skowrońska 2019, pp. 10, 15-16 and 27). This means that owing to the lack of company trade union organizations in such a large number of workplaces, the statutory model of the powers vested in a trade union organization, especially in its sensitive areas, cannot be properly implemented for a long time and therefore remains ineffective. First of all, it is the legislator that is to blame for such a state of affairs, as, having granted the powers to the company trade union organization, it does not see the need to periodically monitor the possibility of their effective implementation in practice and possible adjustment of legal provisions in this respect to the changing socio-economic conditions and rules of the contemporary labour market, although it should also be borne in mind that the creation and functioning of trade union structures, i.e. the possibility of exercising trade union rights, is affected by non-legislative factors, especially reluctance or at least a 'reservedness' that the employees may feel towards creating or joining a trade union, which is dictated by concern over possible loss of employment?

An example of the legislator's passive attitude, which has a direct impact on the functioning of the statutory model of the powers vested in trade unions at the workplace level, is the maintenance of inter-company trade union organizations as the only alternative to company trade union organizations. Inter-company trade unions, which cover more than one employer, were introduced into Polish labour law in 1985 in order to facilitate the association of workers employed by the smallest employers (see Art. 1(6) of the Act of 24 July 1985 on amending the act on trade unions and certain other acts that determine the powers of trade unions, Dz.U. 1985, No. 35, item 162). However, this protective regulation did not meet expectations and is of little use. It turns out that inter-company trade unions work well in workplaces where there are shared interests of employees resulting "either from a well-established sense of professional solidarity (e.g. education, health service), or from connections (organizational, related to capital) between employers" (Latos-Miłkowska 2012, p. 123). However, it is completely different in places where it is difficult to see such shared interests. This applies, for example, to the already mentioned microenterprises operating in competition with one another. One of the reasons why such employers have a small number of inter-company trade union organizations is probably the defective legal structure of these organizations. Doubts are raised in particular by "transferring the model of the company trade union organization to a greater number of workplaces belonging to different employers" and, consequently, by the possibility of the representing of employees of a given employer by trade union activists employed by other, sometimes competitive employers (Hajn 2012, p. 47). Inter-company trade union organizations do not correspond to the specificity of collective employment relationships, because, unlike trade union organizations, they are not "inextricably linked to a particular crew and employer by a specific legal bond and, to a large extent, by a shared interest" (Piątkowski 2014b, p. 72).

In the judgment of 28 September 2006 (K 45/04, OTK-A 2006, No. 8, item 111) the Constitutional Tribunal failed to notice the indicated shortcomings. It decided that the inability of a company trade union organization to operate in small companies (due 
to the adopted numerical threshold of at least 10 eligible members) does not violate the Constitution, especially owing to the need for more efficient management of small workplaces and the possibility of creating inter-company trade union organizations. In so doing, the Tribunal seems to suggest that the activities of company trade union organizations, unlike those of the inter-company trade unions, constitute a barrier to the sound management of an enterprise and infringe economic freedom. Such an argument is not convincing for one essential reason. For if the functioning of a company trade union organization in a small workplace is to be an obstacle (barrier) to its efficient management and is to infringe economic freedom, then the transfer of practically all the powers vested in the company trade union organization to the inter-company trade union organization does not remove the barriers in question.

Despite the fact that it has been long known that the possibility of the operation of trade unions in the smallest employers is not effectively ensured, the legislator has not proposed any new legal solutions that would allow the functioning of the indicated organizations in the vast majority of workplaces in Poland. The extension of the scope of the subjective right of coalition by way of amending the act on trade unions of July 2018 (the Act of 5 July 2018 amending the act on trade unions and certain other acts, Dz.U. 2018, item 1608) cannot be considered to be such a solution. Although the drafter assumed that the extension of the right of coalition to new persons would increase unionization among employers, nevertheless, it is difficult to expect that this would in itself lead to a change in the situation, especially considering the fact that the dependence of trade union rights on the organization's membership of at least 10 members with a specified status was maintained. It seems that in order to ensure that trade unions can function in most workplaces, including the smallest ones, more far-reaching changes to the trade union movement model would be necessary. This has been the subject of lively discussion in the study of labour law for some time now, where various solutions are proposed, ranging from the lowering or even abolishing of the requirement to associate a minimum number of 10 members as a criterion for a trade union organization to have the powers of a company trade union organization (Szmit 2013, p. 385; Piątkowski 2014b, pp. $86 \mathrm{ff}$ ), through allowing trade union organizations other than the company trade union organizations-e.g. trade union delegates- to operate at company level as well, (Hajn 2012, pp. 50 ff; Stelina 2013, pp. 165-166; Szmit 2013, p. 386; Łaga 2014, pp. $130 \mathrm{ff}$ ), to the most radical propositions for removing trade unions from workplaces (Mitrus 2016, p. 160).

The diversity of the proposals that are put forward shows that it is certainly not easy to create the right legal framework for trade unions to operate at company level. This, however, does not justify the lack of action on the part of the legislator, who seems to underestimate the problem on the one hand, and on the other-not to understand the idea of partnership of entities participating in the social dialogue. It can be assumed that the legislator's omission is to some extent also politically motivated.

For the reasons mentioned above, employees of the majority of workplaces in Poland are deprived of the possibility of shaping their legal status through a trade union 
representation. This must raise strong opposition, especially in the context of the fact that trade union powers in areas sensitive for employees should be universally applicable in the legislator's assumption, which is confirmed by such provisions as Art. 20 and 59(2) of the Constitution or at least Art. $77^{1}$ and $77^{2}$ of the Labour Code Act of 26 June 1974 (Dz.U. 2019, item 1040 consolidated text, as amended, hereinafter referred to as: "The Labour Code," "l.c."). However, the vast majority of employers cannot and do not conclude collective labour agreements or other agreements of a collective nature. The content of the payroll regulations cannot be and is not agreed upon, even in companies with more than 10 employees, but less than the statutory employment threshold, which obliges the employer to agree on the content of the regulations with the company trade union organization. The legislator, every now and again raising the numerical threshold of employees (from 5 to as many as 50 people), which determines the obligation of the employer to publish payroll regulations and, consequently, to agree the content of the regulations with the trade union organization, has taken a direction which is contrary to the idea of a broad social dialogue at the level of workplaces. Such a situation contradicts the general assumptions that result from Art. $77^{1}$ and $77^{2}$ of the l.c. that the conditions of remuneration for work and granting other work-related benefits are determined by collective labour agreements or payroll regulations. The Labour Code is a manifestation of the uniformity of labour law. Therefore, if the general principle of shaping remuneration for work and granting other work-related benefits in the company law acts created through dialogue of social partners is expressed in the regulations, then the possibility of exercising the right to collective protection of employees in this area should apply to at least the majority of employees subject to the Labour Code, which is not the case. A significant number of employees are, by definition, outside the scope of trade union organizations and, as a result, outside the scope of collective protection in the sphere of systemic shaping of the conditions of remuneration for work. It is justified in this context to conclude that Art. $77^{1}$ and $77^{2}$ of the l.c. and Art. $25^{1}(1)$ of the a.t.u, which make the exercise of trade union rights conditional on the association of 10 eligible members, are in a normative contradiction with each other.

No possibility of the universal exercise of powers by the company trade union organization has even more far-reaching ramifications. If the powers of a company trade union organization are to demonstrate the position of this organization in the workplace system and in the area of social dialogue, there is a visible discrepancy between the legal and actual strength of the trade union organization. This means that the regulation concerning the powers of a company trade union organization, in its current form, is not able to fully implement the social policy objectives set by the legislator (Piątkowski 2014a, pp. 97-127). Such a regulation proves there is a crisis in the trade union movement in Poland, which was supposed to be based on the strength of the powers of its company structures, as well as a crisis of the social dialogue at the level of workplaces. While the Constitution, by highlighting the dialogue of social partners in Art. 20 and 59(2), underlines its importance and gives it a general legal framework, ordinary 
legislation should provide for such detailed solutions as would shape the conditions ensuring the implementation of the idea of dialogue, also at the level of workplaces. Dialogue does not have to be implemented by the social partners in full, but opportunities for its functioning must be fully created (Piątkowski 2014b, pp. 68-69). The basic, but not the only, condition for the implementation of the idea of company dialogue of social partners with the participation of trade union representation is the universality of dialogue, which is particularly strongly characterized by the adjective "social". In Polish legal reality, the dialogue between social partners at the workplace level is devoid of the already mentioned universality. Therefore, it deserves to be assessed negatively. If social dialogue, within the meaning of Art. 20 of the Constitution, is to be assessed through the prism of structural links in this dialogue, and one of them i.e. the most important one, is weak, then the overall assessment of social dialogue cannot be positive. At the level of workplaces, dialogue in the theoretical and legal aspect and dialogue in action are worlds apart. They have common areas of reference, but only in larger workplaces and usually only in specific industries.

The crisis in the field of social dialogue in Poland deepens the monopoly of the trade union in the creation of company regulations and in conducting collective disputes and announcing industrial actions (more broadly: Rutkowska 2016, pp. 222-241). In the doctrine of labour law, a lively exchange of views on this subject has been taking place for a long time now. The supporters and opponents of the union's monopoly are divided and they quote important arguments to support their positions. The discussion seems to focus on determining the areas of influence of trade union and non-union representation. The prevailing view is that the granting of the powers of a trade union organization to another form of representation, if the trade union organization does not exist in the case of a given employer, will weaken the trade union movement. Undoubtedly, such argumentation leads to the loss of the fundamental objective of the trade union organization's activity at the workplace level, also in terms of concluding collective labour agreements and shaping the content of payroll regulations, as well as initiating collective disputes and announcing strikes. This is not about protecting and strengthening the interests of a trade union organization or other representation through dialogue. These actors are only a tool to achieve the overarching goal. Ensuring social peace at the workplace by protecting the fundamental rights of those who are employed by their representatives is such an overarching, targeted, and strategic goal.

In a situation where the strategic goal cannot be achieved owing to the lack of trade union organizations in the majority of workplaces, it is necessary to consider whether the time of a trade union monopoly in areas so sensitive for workers should not come to an end. Of course, in places where trade unions do operate, only they would still have the right to co-create company regulations and to conduct collective disputes and announce industrial actions. This is supported by the long-standing tradition of trade union organizations exercising these rights, as well as by their close links with trade union freedoms, including freedom of association and the right to negotiations. It is also important for trade unions to be given a special position under international law (Art. 5 of 
ILO Convention No. 135 of 23 June 1971 concerning the protection of employees' representatives in enterprises and the granting of facilitation to them, Dz.U. 1977, No. 39, item 178) and the Constitution (Art. 59).

However, for employers with no trade unions, trade union rights in this area could be part of non-union representation. This is necessary for the realization of the idea of the right of employees to systemically shape the principles of remuneration for work and the right to collective dispute and industrial action. Such a solution is also supported by the principle of negative trade union freedom, according to which non-members not only have the right to remain outside trade unions without suffering negative consequences for this reason, but also their rights cannot be smaller, and their protection cannot be weaker than in the case of people who are affiliated (Seweryński 2005, p. 21). As is aptly emphasised in the literature on the subject, it should also be possible to protect the rights and interests of employees (currently-people who perform gainful employment) outside trade unions (Seweryński 2005, p. 21) and, consequently, "trade union freedom cannot be given such a meaning as would lead to the monopolization of employee collective rights by trade unions" (Seweryński 2000, p. 120).

The question remains whether the abandonment of the trade union monopoly should apply to all the powers that trade union organizations are entitled to on an exclusive basis. There is no consensus in the science of labour law on this subject. The most farreaching solution would be to grant to the non-union representation both the right to conclude collective labour agreements and other agreements of a collective nature and to participate in the shaping of the content of regulations, as well as the right to conduct collective disputes and to announce industrial action (for a departure from the trade union monopoly in concluding agreements, see, inter alia: Sierocka 2009, pp. 267-268; Baran 2010, p. 81; and for collective disputes, see, e.g. Cudowski 2010, p. 247; Rutkowska 2016 , pp. $239 \mathrm{ff})$. On the other hand, a less radical option is also possible, i.e. to phase out the trade union monopoly while monitoring how new solutions work in practice and, above all, whether they create conditions for social peace at the workplace by adequately protecting through their representatives the rights and interests of people who perform gainful employment. This option could be applied in the first place to the systemic shaping of the principles of remuneration for work in the payroll regulations. In workplaces where there are no trade union organizations, the right to determine the content of the payroll regulations could be delegated to a non-union representation. Such a solution is not opposed by international standards or the Constitution (Rutkowska 2016, pp. 235-238).

However, in order not to make the same error related to the lack of a trade union at the majority of employers in Poland, the right to agree on the content of the payroll regulations should not be transferred to an entity that rarely occurs in companies, i.e. the works council. In this context, it is particularly important to ensure the presence of non-union representation in workplaces and to give it a proper legal status, so that it can actually operate and benefit from new powers taken over from trade union organizations. The example of the works council shows how difficult this task can be. 
IV. In the context of the conducted deliberations, it is legitimate to make a statement that if the legislator has given priority to social dialogue at the workplace level with the participation of trade union representation and for this purpose adopted a specific (company) model of trade union organization powers, and such a model cannot be effectively implemented owing to a clear lack of appropriate legal instruments (tools), it is necessary to introduce changes in the collective labour law system (Piątkowski 2012, p. 81), even at the price of breaking with tradition. The lack of action in this area, which has been going on for a long time now, is unacceptable. It is primarily that lack of reaction that the concerns about the future of the trade union movement in Poland are associated with.

It is obvious that the legislator should not care about detailed regulations concerning a specific legal structure in the first place, if it does not provide conditions for the creation of such a structure. On the basis of this assumption, it should be assumed that the expected changes in trade union law should enable real (and not only model-theoretical) trade union activity in the universal system, i.e. at the majority of employers in Poland. It is only then that the care for the quality of detailed regulations related to the functioning of the trade union organization, e.g. with regard to the representativeness of the trade union or the protection of trade union activists against losing their jobs, which is nowadays all too visible in the activity of the legislator, starts making sense. This means that the amendment of the law should take into account, to a greater extent than before, the interests of people who perform gainful employment at workplaces not covered by the activities of trade union organizations, which is confirmed by the teaching of law. There is no doubt that these people should also have the right to negotiate the principles of remuneration and the possibility to take part in collective disputes, for the sake of maintaining civil peace.

In the search for new legal solutions, one should not lose sight of the need to strengthen the position of Polish employers, resulting from the need to make the principle of equality of social partners in collective employment relationships more realistic and the need to strengthen the protection of legitimate interests of employers, especially in terms of enabling them to adjust the statutory conditions of remuneration for work to the dynamically changing situation on the market (more broadly: Rutkowska 2017, pp. $259 \mathrm{ff}$ ) or the admissibility of conducting collective actions (Skąpski 2014, pp. 813-847).

The change in the law must also be correlated with non-legal activities aimed at making the company social dialogue more realistic and stimulating, with the participation of trade union representation. In this respect, one should notice the need to raise social awareness of the benefits that the people performing gainful employment may have from having trade union representation or a general representation at their workplace. A representation, including a non-union representation, which exercises certain rights, is not only a legal value, but also a social one. 


\section{References}

Baran K. W. (2010) Autonomiczne prawo pracy - de lege lata $i$ de lege ferenda [in:] A. Wypych-Żywicka, M. Tomaszewska, J. Stelina (red.), Zbiorowe prawo pracy w XXI wieku, Gdańsk. Baran K. W. (2019) [in:] K. W. Baran (red.), Zbiorowe prawo zatrudnienia. Komentarz, Warszawa. Cudowski B. (1998) Spory zbiorowe w polskim prawie pracy, Białystok.

Cudowski B. (2010) Reprezentacja zatrudnionych w sporach zbiorowych pracy (de lege lata $i$ de lege ferenda) [in:] A. Wypych-Żywicka, M. Tomaszewska, J. Stelina (red.), Zbiorowe prawo pracy w XXI wieku, Gdańsk.

Departament Badań Społecznych i Urząd Statystyczny w Krakowie (A. Auriga-Borówko, A. Fediuk, K. Goś-Wójcicka, T. Sekuła) (2019), Partnerzy dialogu społecznego - organizacje pracodawców i zwiazki zawodowe w 2018 r. (wyniki wstęne), https://stat.gov.pl/obszary-tematyczne/ gospodarka-spoleczna-wolontariat/gospodarka-spoleczna-trzeci-sektor/partnerzy-dialogu-spolecznego-zwiazki-zawodowe-i-organizacje-pracodawcow-wyniki-wstepne, 16, 1.html (access: 20 September 2019).

Gładoch M. (2008) Zakładowe organizacje związkowe w systemie przedstawicielstwa pracowników, „Praca i Zabezpieczenie Społeczne”, nr 9.

Goździewicz G. (1996) Układy zbiorowe pracy. Regulamin wynagradzania. Regulamin pracy. Po nowelizacji kodeksu pracy. Komentarze, Bydgoszcz.

Goździewicz G., Myszka Z., Piątkowski J. (1991) Uprawnienia związków zawodowych w stosunkach pracy, Gdańsk.

Góral Z. (red.) (2013) Układy zbiorowe pracy. W stulecie urodzin profesora Wacława Szuberta, Warszawa.

Grzebyk P. (2019) Od rządów siły do rządów prawa. Polski model prawa do strajku na tle standardów unijnego i międzynarodowego prawa pracy, Warszawa.

Hajn Z. (2002) Ustawowy model organizacji polskiego ruchu związkowego i jego wpływ na zbiorowe stosunki pracy [in:] Prawo pracy a wyzwania XXI wieku. Księga Jubileuszowa Profesora Tadeusza Zielińskiego, Warszawa.

Hajn Z. (2012) Związkowe przedstawicielstwo pracowników zakładu pracy w Polsce - ewolucja, stan obecny, przyszłość [in:] Z. Hajn (red.), Związkowe przedstawicielstwo pracowników zakładu pracy, Warszawa.

Latos-Miłkowska M. (2012) Międzyzakładowa organizacja związkowa [in:] Z. Hajn (red.), Związkowe przedstawicielstwo pracowników zakładu pracy, Warszawa.

Łaga M. (2014) Delegat załogi oraz delegat zwiazku zawodowego jako partnerzy w zakładowym dialogu społecznym - uwagi de lege ferenda [in:] J. Stelina (red.), Zakładowy dialog społeczny, Warszawa.

Mitrus L. (2016) Non-trade Union Employee Representation Selected in Accordance with Procedures Adopted by Individual Employers [in:] J. Carby-Hall, M. Rycak (eds.), Trade Unions and Non-union Employee Representation in Europe: The Current State of Play and Prospects for the Future, Warsaw.

Musiała A. (2013) Porozumienia zbiorowe jako źródło prawa pracy, Poznań.

Nowacki J., Tabor Z. (1994) Wstęp do prawoznawstwa, Warszawa. 
Piątkowski J. (2008) Uprawnienia zakładowej organizacji związkowej, Toruń.

Piątkowski J. (2012) Związek zawodowy jako podmiot zbiorowego prawa pracy [in:] G. Goździewicz (red.), Aktualne problemy zbiorowego prawa pracy w Polsce i w Niemczech, Torun.

Piątkowski J. (2014a) Polityka społeczna a zbiorowe prawo pracy [in:] K. W. Baran (red.), System prawa pracy, t. 5: Zbiorowe prawo pracy, Warszawa.

Piątkowski J. (2014b) Przedstawicielstwo związkowe jako podmiot zakładowego dialogu społecznego [in:] J. Stelina (red.), Zakładowy dialog społeczny, Warszawa.

Pisarczyk Ł. (2019) Reforma zbiorowego prawa pracy. Próba kodyfikacji a nowelizacja przepisów zbiorowego prawa pracy, Warszawa.

Rutkowska B. (2016) The Monopoly of Trade Unions in the Shaping of the Terms and Conditions of Remuneration for Work and Resolving Collective Disputes from the Perspective of the Protection of Rights and Interests of Employees [in:] J. Carby-Hall, M. Rycak (eds.), Trade Unions and Non-union Employee Representation in Europe: The Current State of Play and Prospects for the Future, Warsaw.

Rutkowska B. (2017) Stabilność regulaminowych warunków wynagradzania za prace [in:] M. Szabłowska-Juckiewicz, B. Rutkowska, A. Napiórkowska (red.), Tendencje rozwojowe indywidualnego i zbiorowego prawa pracy. Ksiega jubileuszowa Profesora Grzegorza Goździewicza, Toruń.

Rutkowska B. (2019) Liczba członków jako kryterium posiadania uprawnień zakładowej organizacji związkowej po nowelizacji ustawy o związkach zawodowych z 2018 roku, „Studia z Zakresu Prawa Pracy i Polityki Społecznej", nr 3.

Salwa Z. (1998) Uprawnienia związków zawodowych, Bydgoszcz.

Seweryński M. (2000) Problemy statusu prawnego związków zawodowych [in:] G. Goździewicz (red.), Zbiorowe prawo pracy w społecznej gospodarce rynkowej, Torun.

Seweryński M. (2005) Wybrane problemy konstytucyjne kodyfikacji prawa pracy [in:] H. Szurgacz (red.), Konstytucyjne problemy prawa pracy i zabezpieczenia społecznego, Wrocław.

Sierocka I. (2009) Równowaga a równość stron układów zbiorowych pracy [in:] A. Świątkowski (red.), Ochrona praw człowieka w świetle przepisów prawa pracy i zabezpieczenia społecznego, Warszawa.

Skąpski M. (2014) Lokaut [in:] K. W. Baran (red.), System prawa pracy, t. 5: Zbiorowe prawo pracy, Warszawa.

Stelina J. (2013) Zbiorowa ochrona pracowników u małych i średnich pracodawców [in:] G. Goździewicz (red.), Stosunki pracy u małych pracodawców, Warszawa.

Szmit J. (2013) Oczekiwania zmian ustawodawstwa pracy w zakresie statusu prawnego pracowników zatrudnionych przez małych pracodawców z perspektywy związków zawodowych [in:] G. Goździewicz (red.), Stosunki pracy u małych pracodawców, Warszawa.

Świątkowski A. (red.) (1984) Kompetencje związków zawodowych, Warszawa-Kraków.

Zakrzewski R., Skowrońska A. (red.) (2019) Raport o stanie sektora małych i średnich przedsiębiorstw w Polsce, Warszawa, https://www.parp.gov.pl/storage/publications/pdf/2019_07_ROSS.pdf (access: 20 September 2019). 


\section{Court sentences}

Judgment of the Constitutional Tribunal of 28 September 2006, K 45/04, OTK-A 2006, No. 8, item 111 .

\section{Legal acts}

ILO Convention No. 135 of 23 June 1971 concerning the protection of employees' representatives in enterprises and the granting of facilitation to them, Dz.U. 1977, No. 39, item 178.

The Labour Code Act of 26 June 1974, Dz.U. 2019, item 1040 consolidated text, as amended. The Act of 24 July 1985 on amending the Act on trade unions and certain other acts that determine the powers of trade unions, Dz.U. 1985, No. 35, item 162.

The Act of 23 May 1991 on trade unions, Dz.U. 2019, item 263 consolidated text.

The Constitution of the Republic of Poland of 2 April 1997, Dz.U. 1997, No. 78, item 483 as amended.

The Act of 5 July 2018 amending the Act on trade unions and certain other acts, Dz.U. 2018, item 1608 . 